\title{
PERAN JARINGAN SOSIAL NELAYAN PADA PEMASARAN TUNA, CAKALANG DAN TONGKOL: STUDI KASUS DI KOTA KENDARI
}

\section{The Role of Fishers Social Networking of Thunnus Sp. Commodity Marketing: A Case Study in Kendari}

\author{
*Riesti Triyanti, Christina Yuliaty dan Tenny Apriliani \\ Balai Besar Penelitian Sosial Ekonomi Kelautan dan Perikanan \\ Gedung Balitbang KP I Lt. 4 \\ Jalan Pasir Putih Nomor 1 Ancol Timur, Jakarta Utara \\ Telp: (021) 64711583 Fax: 64700924 \\ *email: riesti_ok@yahoo.com \\ Diterima 14 Agustus 2014 - Disetujui 3 Nopember 2014
}

\begin{abstract}
ABSTRAK
Mayoritas nelayan di Indonesia adalah kategori nelayan tradisional yang miskin serta menjadi golongan terpinggirkan. Sulitnya akses finansial ke lembaga keuangan formal menjadikan ketergantungan nelayan terhadap pinjaman dari pemberi modal informal yang berpengaruh pada pemasaran hasil ikan tangkapan. Studi ini bertujuan untuk mengeksplorasi karakteristik nelayan, proses dan jaringan sosial antar pelaku usaha penangkapan dan pemasaran. Pengumpulan data primer dilaksanakan melalui wawancara mendalam menggunakan panduan wawancara. Data yang terkumpul dianalisis secara deskriptif kualitatif. Hasil penelitian menunjukkan bahwa nelayan di Kota Kendari melakukan aktifitas penangkapan ikan berdasarkan pada jenis alat tangkap yang dimiliki dengan ukuran kapal lebih kecil dari 30 GT. Pemasaran tuna, cakalang dan tongkol dikelompokkan kedalam dua pasar utama yaitu pasar lokal dan ekspor. Bagi nelayan yang memperoleh permodalan untuk melaut dari bos maka pemasaran ikan hasil tangkapan dikendalikan oleh bos. Jaringan sosial yang melibatkan berbagai aktor tidak hanya terbatas pada jaringan kerja pada produksi saja, namun juga atas kehidupan sosial ekonomi lainnya. Diantara berbagai jaringan sosial yang ada, yang paling prospektif untuk dikembangkan dalam komunitas nelayan di Kendari adalah jaringan sosial antara nelayan dengan bos dengan pola kemitraan inti plasma.
\end{abstract}

Kata Kunci: jaringan sosial, pelaku pemasaran, nelayan, purse seine

\begin{abstract}
The majority of Indonesian fishers are traditional and small scale fisheries which are also considered as poor and marginal group. Limited access of finance to any formal finance institutions make them highly depend on informal loan sources, such as money lenders which will have impacts to their fish production marketing. The objective of this paper is studying fishers' characteristics and also any social networks practices among fisher and marketing actors. Primary data were collected using indepth interview technique with interview guidance notes. Whereas collected data were analyzed using descriptive technique. Results indicated that fishers in Kendari were mostly less than 30 GT. Marketing of tuna, skipjack and baby tuna were classified into two groups namely local and export market. Fishers who had finances for their operational from boss (juragan) caused their marketing was controlled by boss (juragan). Social networks who involved many actors was not only limited to production mode but also other socio economic aspects. It was also indicated that among other existing social networks in the Kendari fishers' community, social network between fishers and bos (juragan) was more potential to develop using "inti-plasma" partnership.
\end{abstract}

Keywords: social networks, marketing actor, fisher, purse seine 


\section{PENDAHULUAN}

Mayoritas penduduk di Kota Kendari bertempat tinggal di daerah pinggiran pantai dan berprofesi sebagai nelayan. Posisi nelayan di Kota Kendari tergolong dalam profesi dengan kesejahteraan yang cukup rendah atau miskin. Masyarakat nelayan merupakan manusia yang hidup berkelompok. Begitu juga masyarakat nelayan yang ada di sekitar PPI Sodoha dan PPS Kendari yang mayoritas merupakan suku bugis. Kota Kendari sebagai salah satu produsen ikan jenis pelagis besar dan ikan demersal yaitu tuna, tongkol, cakalang, layang, tembang, tenggiri, kerapu, ekor kuning dan cumi-cumi. Produksi perikanan tahun 2012 tercatat sebanyak 28.027,43 ton dengan nilai Rp. 296.448.003,- atau mengalami peningkatan volume dari tahun 2011 sebesar $1,01 \%$ dan nilai sebesar $1,05 \%$. Tiga jenis ikan dengan produksi terbanyak yaitu ikan cakalang yaitu sebesar $9.598,25$ ton, ikan layang sebesar $7.273,54$ ton dan ikan tongkol sebesar $5.954,51$ ton. Kapal yang digunakan berukuran 29-50 GT dengan alat tangkap purse seine dan pole and line (BPS, 2013).

Kelompok nelayan memiliki ketergantungan yang sangat tinggi terhadap kondisi alam pada saat melakukan kegiatan melaut. Menurut Kusnadi (2002) dalam Amirudin (2014) bahwa perangkap kemiskinan yang melanda kehidupan nelayan disebabkan oleh faktor-faktor yang kompleks. Faktor-faktor tersebut tidak hanya berkaitan dengan fluktuasi musim-musim ikan, keterbatasan sumber daya manusia, modal serta akses, jaringan perdagangan ikan yang eksploitatif terhadap nelayan sebagai produsen, tetapi juga disebabkan oleh dampak negatif modernisasi perikanan yang mendorong terjadinya pengurasan sumberdaya laut secara berlebihan. Kondisi itu terjadi secara langsung, sehingga jaringan sosial pada komunitas nelayan semakin kuat, karena adanya kepentingan dan saling menguntungkan.

Nelayan tradisional dengan skala usaha kecil lebih banyak yang bersifat subsisten dalam mempertahankan hidup keluarganya. Berbagai keterbatasan akses jaringan sosial bagi nelayan tradisional menyebabkan butuhnya bantuan orang yang berada di luar komunitasnya. Pada dasarnya jaringan sosial terbentuk karena adanya rasa saling tahu, saling menginformasikan, saling mengingatkan, dan saling membantu dalam melaksanakan ataupun mengatasi sesuatu. Intinya, konsep jaringan dalam modal sosial menunjuk pada semua hubungan dengan orang atau kelompok lain yang memungkinkan kegiatan dapat berjalan secara efisien dan efektif (Lawang, 2005).

Untuk memperkuat ketahanan hidup komunitas nelayan tradisional, maka kehadiran jaringan sosial pemilik modal sangat diperlukan untuk keberlangsungan usaha nelayan tradisional. Sebagai nelayan tradisional memiliki keterbatasan dalam menciptakan jaringan-jaringan sosial permodalan. Damsar (2002) dalam Amirudin (2014) menyatakan bahwa jaringan sosial merupakan hubungan-hubungan yang tercipta antarbanyak individu dalam suatu kelompok ataupun antar suatu kelompok dengan kelompok lainnya. Hubunganhubungan yang terjadi bisa dalam bentuk yang formal maupun bentuk informal. Selain jaringan sosial permodalan, yang terpenting pula dan merupakan aspek paling akhir yaitu pemasaran hasil tangkapan.

Nelayan diperhadapkan oleh ketergantungan pemasaran, yaitu mekanisme pemasaran melalui pemilik modal. Pemasaran melalui pemilik modal merupakan pilihan yang diperkuat melalui ketergantungan kontrak sosial melalui nilai-nilai kepercayaan. Ketergantungan nelayan pada pemilik modal, merupakan suatu ikatan-ikatan sosial yang menjadi pegangan untuk memperoleh pemenuhan kebutuhan hidupnya. Sebagaimana Amiruddin (2014), menggambarkan bahwa peran jaringan sosial terhadap pemasaran hasil tangkapan digolongkan dalam bentuk pemasaran melalui pemilik modal merupakan pilihan yang diperkuat melalui ketergantungan kontrak sosial melalui nilai-nilai kepercayaan. Ketergantungan nelayan pada pemilik modal, merupakan suatu ikatan-ikatan sosial yang menjadi pegangan untuk memperoleh pemenuhan kebutuhan hidupnya. Sedangkan penelitian Sallatang (1982) menunjukkan bahwa hubungan antara patron dengan klien dalam pemasaran ikan di daerah Sulawesi merupakan hubungan kepentingan yang diperkuat oleh hubungan kerabat. Lebih lanjut, Ningsih (2009) menyatakan bahwa untuk tetap bertahan, nelayan membentuk lebih dari satu jaringan sosial, yaitu jaringan kapten dengan anak buah kapal (ABK), jaringan kapten dengan tauke, jaringan tetangga, dan jaringan kerabat.

Peran jaringan sosial dalam sistem pemasaran ikan sangat berpengaruh dalam penentuan harga ikan itu sendiri. Jaringan sosial antara nelayan sebagai produsen dengan pelaku usaha pemasaran lain memiliki aturan main yang 
telah disepakati oleh kedua pihak. Komunitas nelayan purse seine di Kota Kendari, merupakan komunitas nelayan yang selama ini melakukan mekanisme pemasaran melalui ketergantungan pada pemilik modal, namun dari berbagai bentuk jaringan sosial yang ada, belum dikaji lebih lanjut jaringan sosial yang dirasakan menguntungkan bagi nelayan. Penelitian ini bertujuan untuk mengkaji peran berbagai bentuk jaringan sosial terhadap kegiatan pemasaran Tuna, cakalang dan tongkol (TCT) termasuk di dalamnya karakteristik nelayan purse seine di sekitar PPI Sodoha Kota Kendari, proses pemasaran komoditas TCT dan jaringan sosial lain yang ada di Kota Kendari. Hasil penelitian ini diharapkan dapat dijadikan bahan pertimbangan kebijakan pemerintah Kota Kendari maupun Kementerian Kelautan dan Perikanan agar menjadikan jaringan sosial nelayan dengan pemilik modal menjadi pola kemitraan yang difasilitasi oleh pemerintah, sehingga memiliki dampak positif terhadap kehidupan sosial ekonomi nelayan.

\section{METODOLOGI}

\section{Waktu dan Tempat Penelitian}

Penelitian ini dilakukan pada Bulan Mei 2014 di Kota Kendari, Sulawesi Tenggara yaitu di Pangkalan Pendaratan Ikan (PPI) Sodoha dan Pelabuhan Perikanan Samudera (PPS) Kendari. Lokasi tersebut dipilih secara sengaja (purposive) karena merupakan salah satu pusat kegiatan penangkapan ikan pelagis besar khususnya tuna, cakalang dan tongkol (TCT) di wilayah pulau Sulawesi yang memasok pasar ke negara Hongkong, Uni Eropa, Jepang, dan Australia.

\section{Pendekatan}

Jenis penelitian yang digunakan dalam penelitian ini adalah penelitian kualitatif. Pemilihan metode kualitatif ini dimaksudkan agar dapat mempelajari, menerangkan atau menginterprestasikan suatu kasus dalam suatu masyarakat secara natural, apa adanya, dan tanpa adanya intervensi dari pihak luar (Harini, 2012).

Pendekatan penelitian yang digunakan adalah studi kasus (case study) dengan Kota Kendari sebagai satuan kasus. Menurut Nazir (1988), penelitian studi kasus adalah suatu penelitian yang dilakukan secara intensif, terinci dan mendalam terhadap suatu organisasi, lembaga atau gejala tertentu. Penelitian kasus jika ditinjau dari wilayahnya, hanya meliputi daerah atau subjek yang relatif sempit, namun apabila ditinjau dari sifat penelitiannya tergolong dalam penelitian yang mendalam.

Pendekatan teoritis yang digunakan dalam penelitian ini adalah pendekatan jaringan sosial. Menurut Ruddy (2007), jaringan sosial ditinjau dari tujuan hubungan sosial yang membentuk jaringan sosial dibagi menjadi tiga jenis yaitu (1) Jaringan kekuasaan (power) yaitu hubungan sosial yang dibentuk oleh hubungan sosial yang bermuatan kekuasaan, atau dibentuk dan sengaja diatur oleh kekuasaan. Jadi, jaringan kekuasaan tidak dapat menyandarkan diri pada kesadaran anggotanya untuk memenuhi kewajiban anggotanya secara sukarela, tanpa insentif, (2) Jaringan kepentingan (interest) yaitu hubungan yang dibentuk oleh hubungan sosial yang bermuatan kepentingan, bermakna pada tujuan-tujuan khusus. Jika tujuan atau kepentingan yang sifatnya konkrit dan spesifik sudah tercapai, hubungan tersebut berakhir. Tapi, jika tujuannya tidak konkrit atau tidak spesifik dan tidak konkrit atau tujuan tersebut selalu berulang, maka struktur yang terbentuk relatif stabil dan permanen dan (3) Jaringan perasaan (sentiment), terbentuk atas dasar hubungan sosial yang bermuatan perasaan dan hubungan sosial itu sendiri menjadi tujuan dan tindakan sosial. Struktur yang dibentuk cenderung mantap dan permanen, sementara hubungannya cenderung dekat dan kontinu. Oleh karena itu muncul adanya saling kontrol secara emosional yang relatif kuat antar pelaku. Pada kenyataannya, sebuah jaringan sosial tidak hanya dibentuk oleh satu jenis sosial di atas. Namun sering terjadi tumpang tindih antara tiga jenis bentuk hubungan sosial tersebut.

\section{Metode Penentuan Narasumber}

Penentuan narasumber nelayan (bos dan nelayan penangkap ikan) dilakukan dengan simple random sampling karena mengedepankan prinsip bahwa sampel memiliki kemungkinan yang sama untuk terpilih secara acak. Sedangkan penentuan narasumber pengolah ikan skala rumah tangga dilakukan dengan purposive sampling dan penentuan narasumber pedagang dilakukan dengan snowball sampling. Metode ini memberikan kesempatan maksimal pada kemampuan peneliti untuk menyusun teori yang dibentuk dari lapangan (grounded theory) dengan sangat memerhatikan kondisi lokal dengan kekhususan nilai-nilainya (idiografis). Teknik penentuan narasumber di dalam penelitian kualitatif sering juga dinyatakan sebagai "internal sampling" karena sama sekali bukan 
dimaksudkan untuk mengusahakan generalisasi tetapi untuk memperoleh kedalaman studi di dalam suatu konteks tertentu.

Narasumber dalam penelitian ini terdiri dari nelayan purse seine, pedagang (pengecer, pengumpul besar, pengumpul kecil) dan pengolah ikan (skala tradisional dan industri). Jumlah narasumber secara rinci disajikan pada Tabel 1.

\section{Metode Pengumpulan Data}

Data primer dikumpulkan melalui wawancara mendalam (indepth interview) terhadap narasumber yang banyak mengetahui tentang alur pemasaran komoditas TCT dan jaringan sosial dalam pemasarannya serta dilakukan observasi lapangan, sedangkan data sekunder dikumpulkan melalui desk study ke Badan Pusat Statistik Kota Kendari. Wawancara mendalam dilakukan dengan bantuan panduan topik data dan log book untuk memperoleh data yang terkait dengan topik penelitian yaitu bentuk-bentuk jaringan sosial, variabel jaringan sosial, dan faktor yang mempengaruhi jaringan sosial. Jenis data primer yang digali dari narasumber terdiri dari: hubungan antar aktor, fungsi jaringan sosial (goal attainment), pemeliharaan pola jaringan. Sedangkan jenis data sekunder yang dikumpulkan dari instansi terkait terdiri dari jumlah nelayan dan jumlah produksi TCT per tahun.

Menurut Ruddy (2007), jaringan sosial ditinjau dari tujuan hubungan sosial yang membentuk jaringan sosial dibagi menjadi tiga jenis yaitu (1) Jaringan kekuasaan (power) yaitu hubungan sosial yang dibentuk oleh hubungan sosial yang bermuatan kekuasaan, atau dibentuk dan sengaja diatur oleh kekuasaan. Jadi, jaringan kekuasaan tidak dapat menyandarkan diri pada kesadaran anggotanya untuk memenuhi kewajiban anggotanya secara sukarela, tanpa insentif,
(2) Jaringan kepentingan (interest) yaitu hubungan yang dibentuk oleh hubungan sosial yang bermuatan kepentingan, bermakna pada tujuantujuan khusus. Jika tujuan atau kepentingan yang sifatnya konkrit dan spesifik sudah tercapai, hubungan tersebut berakhir. Tapi, jika tujuannya tidak konkrit atau tidak spesifik dan tidak konkrit atau tujuan tersebut selalu berulang, maka struktur yang terbentuk relatif stabil dan permanen dan (3) Jaringan perasaan (sentiment), terbentuk atas dasar hubungan sosial yang bermuatan perasaan dan hubungan sosial itu sendiri menjadi tujuan dan tindakan sosial. Struktur yang dibentuk cenderung mantap dan permanen, sementara hubungannya cenderung dekat dan kontinu. Oleh karena itu muncul adanya saling kontrol secara emosional yang relatif kuat antar pelaku. Pada kenyataannya, sebuah jaringan sosial tidak hanya dibentuk oleh satu jenis sosial di atas. Namun sering terjadi tumpang tindih antara tiga jenis bentuk hubungan sosial tersebut.

\section{Metode Analisis Data}

Penelitian ini menggunakan pendekatan sosio-kultur dengan melihat pola-pola jaringan sosial yang akan dianalisis dengan menggunakan pendekatan struktural-fungsional. Analisis ini digunakan untuk memahami kebudayaan suatu masyarakat sederhana berskala kecil (Harini,

2012). Data yang terkumpul dianalisis menggunakan analisis deskriptif yang terdiri dari tiga tahapan yaitu reduksi data, display data, dan penarikan kesimpulan (Cavana et al., 2009). Pada tahap reduksi data, data yang terkumpul dipilih sesuai dengan fokus kajian. Setelah itu dilakukan display data, yaitu mengelompokkan data berdasarkan sub-sub pembahasan yang kemudian disusun secara sistematis dan ditampilkan dalam sebuah matriks. Penampilan dalam sebuah matriks

Tabel 1. Metode Penentuan, Jenis dan Jumlah Narasumber dalam Penelitian.

Table 1. Method of Source Determination, Type and Number of Source in Research.

\begin{tabular}{llc}
\hline $\begin{array}{l}\text { Metode Penentuan Narasumberl } \\
\text { Method of Source Determination }\end{array}$ & \multicolumn{1}{c}{$\begin{array}{c}\text { Jenis Narasumberl } \\
\text { Type of Source }\end{array}$} & $\begin{array}{c}\text { Jumlah Narasumberl } \\
\text { Number of Source }\end{array}$ \\
\hline Simple Random Sampling & $\begin{array}{l}\text { Nelayan/Fishers } \\
\text { Purposive Sampling }\end{array}$ & $\begin{array}{l}\text { Pengolah skala rumah tangga/Fish } \\
\text { processor household scale } \\
\text { Pedagang/Trader }\end{array}$ \\
Snowball Sampling & & 4 \\
\hline
\end{tabular}

Total narasumber / Number of research source 
akan memudahkan untuk melihat hubungan antar sub pembahasan untuk kemudian ditarik sebuah kesimpulan. Studi deskriptif dilakukan dalam rangka untuk memastikan dan juga menggambarkan karakteristik dan variabel-variabel penting suatu situasi. Tujuan dari penelitian deskriptif adalah untuk menggambarkan aspek-aspek yang relevan terhadap fenomena yang menarik dari suatu individu maupun organisasi (Nazir, 1988). Secara skematis, analisis data yang dilakukan adalah seperti disajikan pada Gambar 1.

\section{HASIL DAN PEMBAHASAN}

\section{Karakteristik Nelayan di Kota Kendari}

Nelayan purse seine merupakan nelayan yang menggunakan alat tangkap puncat cincin dengan ukuran kapal antara 29-50 GT. Operasional kegiatan penangkapan setiap tripnya adalah $2-7$ hari dan setiap bulannya jumlah trip berkisar antara 3 - 8 trip (Tabel 2). Total pekerja dalam satu kapal ukuran 29 GT sebanyak 18 orang yang berasal dari berbagai suku diantaranya suku Taulaki, Flores, Jawa dan Muna. Dasar pertimbangan dalam pemilihan nahkoda adalah berdasarkan kepercayaan pemilik (umumnya melihat kinerja terlebih dahulu) sedangkan untuk Anak Buah Kapal $(A B K)$ dipilih oleh nahkoda (umumnya ABK berasal dari luar kota kendari). Terdapat kesulitan untuk mendapatkan ABK karena ABK tidak memiliki ikatan dengan nelayan pemilik sehingga bisa pindah kapal sewaktu-waktu. Pemilihan nahkoda oleh ABK berdasarkan kemudahan untuk bekerjasama dan pembagian hasil yang adil. Pemilihan juragan didasarkan kepada kebaikan dan tidak sulit untuk memberikan pinjaman ketika ada kebutuhan mendadak.

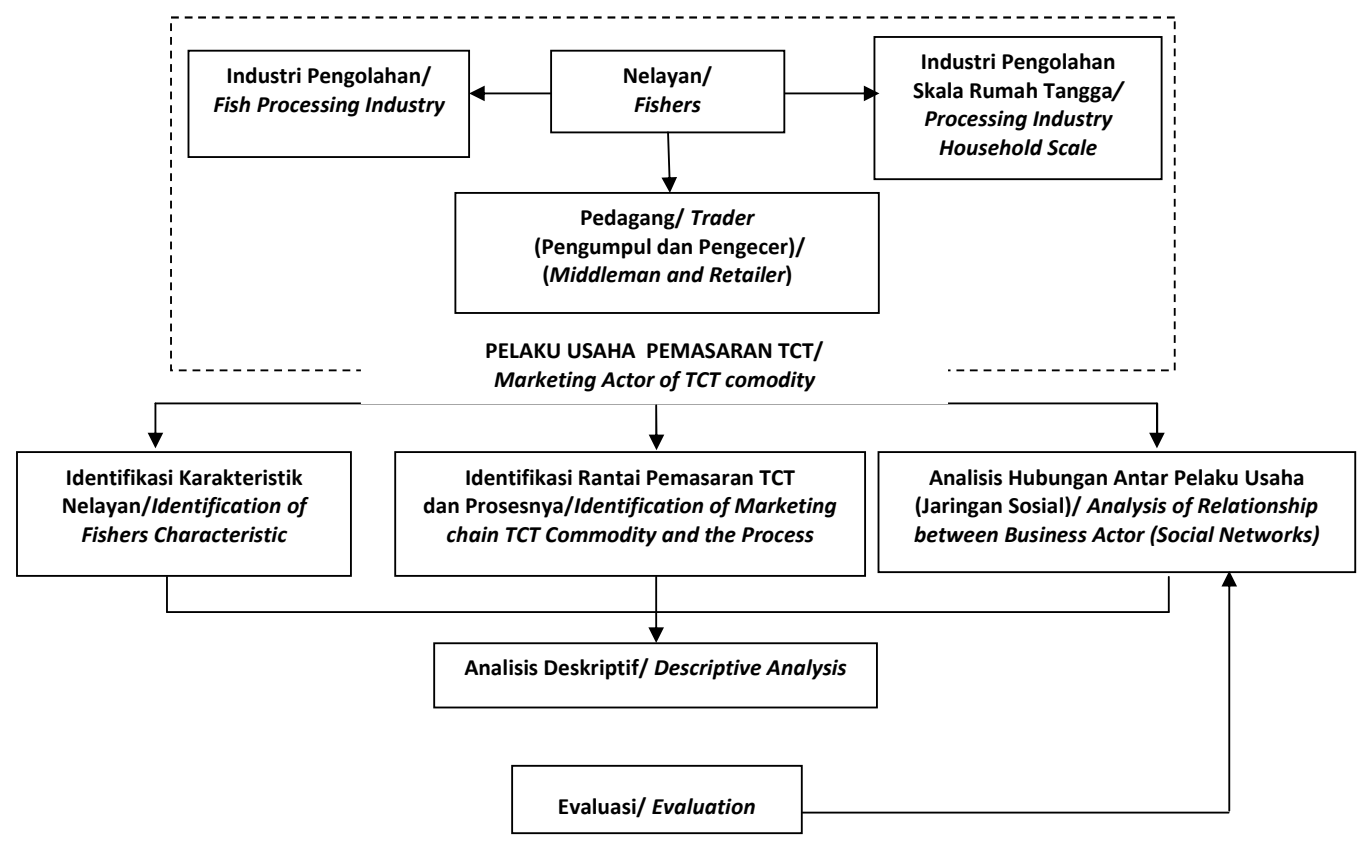

Gambar 1. Skema Analisis Deskriptif Peran Jaringan Sosial Nelayan Purse Seine Pada Pemasaran Ikan TCT di Kota Kendari.

Figure 1. The Sceme of Descriptive Analysis The Role of Purse Seine Fisher Social Networking of Thunnus sp. Commodity in Kendari.

Tabel 2. Kalender Musim Penangkapan Ikan dengan Alat Tangkap Purse seine di Kota Kendari, 2013. Table 2. Calendar Fishing With Purse Seine in Kendari, 2013.

\begin{tabular}{|c|c|c|c|c|c|c|c|c|c|c|c|c|c|c|}
\hline \multirow{2}{*}{ Musim/Season } & \multirow{2}{*}{$\begin{array}{c}\text { Jumlah Hari/ } \\
\text { Trip } \\
\text { Number of } \\
\text { Days/Trip }\end{array}$} & \multirow{2}{*}{$\begin{array}{c}\text { Jumlah Trip/ } \\
\text { Bulan } \\
\text { Number of } \\
\text { Trip/Month }\end{array}$} & \multicolumn{12}{|c|}{ Bulan/Month } \\
\hline & & & 1 & 2 & 3 & 4 & 5 & 6 & 7 & 8 & 9 & 10 & 11 & 12 \\
\hline Puncak / Peak & 2 & 8 & $X$ & & & & & & & & & $X$ & $\mathrm{X}$ & $x$ \\
\hline Sedang / Normal & 5 & 5 & & $\mathrm{X}$ & $\mathrm{X}$ & $X$ & & & & & & & & \\
\hline Paceklik / Famine & 7 & 3 & & & & & $\mathrm{X}$ & $X$ & $\mathrm{X}$ & $\mathrm{X}$ & $\mathrm{X}$ & & & \\
\hline
\end{tabular}

Sumber: Data primer diolah (2014). / Source: Primary data processed (2014). 
Wilayah penangkapan kapal dengan alat tangkap ini adalah di wilayah perairan Pulau Buru, Pulau Sagu hingga Selat Maluku, sedangkan jenis ikan yang tertangkap adalah ikan demersal dan pelagis yaitu ikan layang, kakap,cakalang, kerapu, ekor kuning. Pemasaran hasil tangkapan kapal purse seine ini dikelompokkan kedalam dua pasar utama yaitu pasar lokal dan pabrik. Tidak ada ikatan antara pemilik kapal dan pedagang, penjulan ikan hasil tangkapan berdasarkan harga jual ikan saja. Pasar lokal merupakan pasar setempat, baik di dalam Kota Kendari maupun di luar kota kendari seperti Kolaka Utara. Tujuan pemasaran hasil tangkapan melalui industri pengolahan diantaranya PT. AMO dan PT. Mina Jaya Abadi. Dari sisi harga, harga jual di pasar lokal lebih tinggi dibandingkan harga dari pabrik (margin sekitar Rp 2.000 / $\mathrm{kg}$ ). Nelayan yang meminjam biaya operasional penangkapan harus menjual ikan hasil tangkapan kepada juragan/bos (harga lebih rendah Rp 1.000 / kg dibandingkan harga pasar).

Selain dari sisi harga, jenis ikan antara kedua pasar tujuan juga berbeda, untuk pabrik adalah jenis ikan layang dan cakalang dengan minimal kuantitas 1 ton per trip sedangkan untuk jenis ikan lainnya adalah tujuan pasar lokal. Sistem pembayaran adalah sistem tempo yaitu 1-2 hari, sistem ini berlaku untuk kedua jenis pasar. Sedangkan untuk pembagian hasil antara nelayan dan pemilik kapal tidak dibayarkan setiap trip kapal tetapi per bulan (sistem yang digunakan adalah terang bulan hingga gelap bulan atau ketika kapal istirahat baru bagi hasil dilakukan). Permodalan usaha berasal dari modal sendiri atau bantuan pemerintah (kapal inka mina).

Alat tangkap lainnya yang digunakan oleh nelayan di Kota Kendari adalah pole and line dengan ukuran kapal > 20 GT. Jumlah pekerja dalam satu kapal adalah sebanyak 15 orang yang umumnya berasal dari kota kendari sendiri. Lokasi penangkapan ikan adalah di WPP 714 yaitu Laut Banda. Jumlah hari per trip untuk kapal pole and line tidak ada perbedaan antar musim baik musim puncak, normal maupun paceklik yaitu kurang lebih 20 hari per trip, dan dalam satu bulan hanya 1 trip penangkapan saja (Tabel 3). Untuk kapal pole and line memerlukan umpan untuk menangkap ikan yaitu ikan teri. Umpan tersebut diperoleh dari bagan yang ada ditengah laut. Masing-masing kapal umumnya memiliki langganan bagan lebih dari satu antara 2 - 5 unit bagan. Upaya yang dilakukan untuk mengikat bagan agar tetap menjadi langganan adalah dengan cara memberikan kompensasi misalnya genset atau balon penampung, hal ini salah satu cara untuk mengikat bagan. Meskipun secara riil pelaksanaan ternyata bagan-bagan tersebut bisa saja menjual ikan teri kepada kapal pole and line lainnya.

\section{Sistem Pemasaran Komoditas TCT di Kota Kendari}

Jaringan pemasaran komoditas TCT dari PPI Sodoha terdiri dari 6 (enam) saluran pemasaran. Nelayan sebagai produsen dalam pemasaran komoditas TCT menangkap menggunakan alat tangkap purse seine dan pole and line, sedangkan nelayan bagan adalah nelayan yang memasok kebutuhan ikan teri bagi nelayan pole and line yang akan digunakan sebagai umpan. Salah satu saluran pemasaran sampai ke luar negeri adalah dari nelayan ke eksportir yaitu ke negara Hongkong, Australia dan Jepang dalam bentuk ikan beku. Selain itu tujuan pemasaran ditingkat lokal antara lain warung makan, rumah makan, dan pengolah tradisional. Pemasaran ikan juga dilakukan ke industri pengolahan dan berlanjut dikirim ke Surabaya, Makassar, Jakarta dan Bali.

Pedagang pengumpul besar adalah pedagang yang mendapatkan pasokan ikan dari nelayan langsung atau pengumpul kecil. Modal usaha merupakan modal sendiri. Bahan baku diperoleh langsung dari nelayan (bertindak sebagai juragan modal juga untuk 5 kapal), selain dari nelayan di PPI Sodoha, ketika musim paceklik

Tabel 3. Kalender Musim Penangkapan Ikan dengan Alat Tangkap Pole and Line di Kota Kendari, 2013.

Table 3. Calendar Fishing With Pole and Line in Kendari, 2013.

\begin{tabular}{|c|c|c|c|c|c|c|c|c|c|c|c|c|}
\hline \multirow{2}{*}{ Musim / Season } & \multicolumn{12}{|c|}{ Bulan / Month } \\
\hline & 1 & 2 & 3 & 4 & 5 & 6 & 7 & 8 & 9 & 10 & 11 & 12 \\
\hline Puncak / Peak & & & & & & & & & $\mathrm{X}$ & $X$ & $\mathrm{X}$ & \\
\hline Sedang / Normal & $X$ & $X$ & $x$ & $X$ & & & & & & & & $X$ \\
\hline Paceklik / Famine & & & & & $\mathrm{X}$ & $X$ & $X$ & $\mathrm{X}$ & & & & \\
\hline
\end{tabular}

Sumber: Data primer diolah (2014). / Source: Primary data processed (2014). 
mencari bahan baku sampai ke pulau-pulau (Wakatobi, Wanci, dan Banggai) melalui pedagang pengumpul kecil di pulau. Bahan baku untuk ikan tuna dan ikan karang diperoleh dari daerah di sekitar Kendari sedangkan dari Wakatobi khusus untuk ikan dasar. Penjualan ikan ke pabrik pengolahan/ eksportir (tuna dan ikan dasar-fillet beku), rumah makan (ikan kue), pedagang Makassar (sunu dan kerapu).

Kegiatan pengolahan ikan melibatkan aktor yang dapat dikelompokkan ke dalam dua skala usaha tradisional dengan produk olahan berupa bakso dan ikan asap serta olahan modern yaitu ikan beku yang merupakan konsumsi ekspor. Bahan baku untuk pengolahan ikan ini diperoleh dari pedagang pengumpul langganan (3 orang), alasan bermitra diantaranya adalah kualitas ikan, kepercayaan, kejujuran, dan pembayaran bisa dilakukan setelah ikan laku terjual. Produk olahan ikan yang sudah dikenal baik oleh masyarakat di Kota Kendari dapat dikelompokkan ke dalam dua jenis ikan olahan yaitu olahan tradisional dalam bentuk ikan asap, bakso dan abon serta olahan modern yaitu ikan beku yang merupakan konsumsi ekspor. Aktivitas pengolahan ikan asap mulai berkembang sejak tahun 2000. Informasi teknologi pengolahan berasal dari keluarga secara turun termurun berdasarkan pengalaman teman. Bahan baku diperoleh dari pedagang pengumpul langganan (3 orang). Manfaat lain dari hubungan antara pengolah dan penjual adalah peminjaman uang pada saat kebutuhan mendadak, hal ini bisa berlangsung timbal balik (2 arah). Permodalan usaha berasal modal sendiri dan bantuan pemerintah (Pengembangan Usaha Mina Pedesaan Pengolahan dan Pemasaran Hasil Perikanan / PUMP-P2HP). Ikan asap di pasarkan ke Pasar Andonuhu dan Pasar Baruga serta melalui pedagang keliling. Alur rantai pemasaran TCT di kota Kendari adalah seperti disajikan pada Lampiran 1.

\section{Jaringan Sosial Nelayan Purse Seine dengan Pelaku Usaha Pemasaran Komoditas TCT}

Jaringan sosial terbentuk karena adanya kesamaan dalam produksi dan distribusi sumberdaya yang menyebabkan adanya pihak yang memiliki kekuasaan atau kemampuan untuk mengontrol sumberdaya dan adanya pihak yang dikontrol (Mirajiani et al., 2014). Kedua pihak ini memiliki hubungan saling ketergantungan, oleh karenanya kedua pihak tersebut akan selalu menjaga hubungan agar bisa terus terjalin sehingga sama-sama bisa mengambil manfaat dalam pengelolaan sumberdaya untuk memenuhi kebutuhan hidup keluarganya. Hubungan ini dinamakan hubungan patron-client.

Bentuk-bentuk patronase yang ada di nelayan bersifat sosial dan ekonomi. Dilihat dari status sosial ekonomi individu yang terlibat, terdapat dua jenis jaringan sosial, yaitu jaringan sosial horizontal dan vertikal. Jaringan sosial dikatakan bersifat horizontal jika individu-individu yang terlibat di dalamnya memiliki status sosial ekonomi yang relatif sama. Mereka memiliki kewajiban yang sama dalam perolehan sumber daya, dan sumber daya yang dipertukarkan juga relatif sama. Sebaliknya dalam jaringan sosial yang bersifat vertikal, individu-individu yang terlibat di dalamnya tidak memiliki status sosial ekonomi yang sepadan (Foster, 1967; Wolf, 1978:8 dalam Haryono, 2007). Jaringan sosial yang ada di nelayan memiliki karakteristik yang berbeda antara satu lokasi dengan lokasi lain. Menurut Mirajiani et al. (2014), patronase merupakan suatu alternatif pranata ekonomi nelayan yang dibangun untuk tetap bertahan dengan situasi krisis dan ketidakpastian ekonomi serta mata pencaharian yang bersifat fluktuatif. Sedangkan dampak positif yang bersifat sosial yang dirasakan dalam hubungan patronase adalah "nilai saling berbagi" (shared values) serta pengorganisasian peran (rules) yang diekspresikan dalam hubungan personal (personal relationship), kepercayaan (trust), dan common sense (Syahyuti, 2008).

Dasar yang digunakan dalam melihat jaringan sosial para pelaku perikanan di Kota Kendari adalah data mengenai alur modal kerja dan alur produk. Hubungan para pelaku antar titik-titik dalam alur tersebut tidak hanya mempertimbangkan aspek ekonomi namun didalamnya terlekat aspek sosial yang didasarkan pada motif tertentu. Kondisi ini pun terlihat dalam rantai produksi dan rantai tataniaga ikan di Kota Kendari, misalnya dalam proses penentuan kapten kapal, penetapan harga ikan, dan lain-lain.

Bentuk-bentuk jaringan sosial pemasaran komoditas TCT di Kota Kendari dikelompokkan dalam jaringan sosial yang didasarkan pada status sosial ekonomi individu yang terlibat dan tujuan membentuk jaringan sosial. Ada empat pola jaringan sosial antara pelaku usaha pemasaran TCT di Kota Kendari yaitu jaringan sosial bos dengan pengurus kelompok, jaringan sosial nelayan dengan mitra bagan, jaringan sosial nelayan dengan pedagang 
pengumpul (kecil dan besar) dan jaringan sosial nelayan dengan bos/pemilik modal. Jaringan sosial pemasaran komoditas TCT di Kota Kendari disajikan pada Gambar 2.

\section{Jaringan Sosial Antara Bos dan Pengurus}

'Bos' merupakan pemilik kapal. Nelayannelayan di Kota Kendari umumnya terbagi ke dalam kelompok-kelompok. 'Bos' ini juga merupakan ketua dalam kelompok. Selain sebagai juragan kapal (pemilik kapal), mereka juga berperan sebagai juragan darat yang bertugas membiayai operasional kapal untuk setiap tripnya. Dalam menjalankan perannya, bos dibantu oleh pengurus yang berfungsi sebagai perpanjangan tangannya yang bekerja atas dasar kepercayaan (trust). Jika dikaitkan dengan jenis jaringan sosial, maka hubungan ini tergolong dalam jenis jaringan kekuasaan (Ruddy, 2007), yang berarti bos mempunyai kewenangan penuh untuk mengatur pekerjaan pengurus. Sedangkan jika dilihat dari status sosial ekonomi individu yang terlibat maka jaringan sosial antara bos dengan pengurus tergolong dalam jaringan sosial vertikal (Haryono, 2007).

\section{Jaringan Sosial Bos dengan Mitra Bagan}

Nelayan pool and line, kebutuhan umpan yang cukup besar mengharuskan bos pemilik kapal 'mengikat' pemilik bagan agar mau menjual ikannya ke mereka. Cara 'mengikat'nya adalah dengan menyediakan alat genset dan lampu (balon) sehingga pemilik bagan memiliki ketergantungan dengan bos pool and line. Namun ternyata ikatan ini tidak selalu berjalan dengan baik, terkadang pemilik bagan tetap menjual ikan kepada pihak lain. Satu kapal bisa memiliki 2 hingga 5 mitra

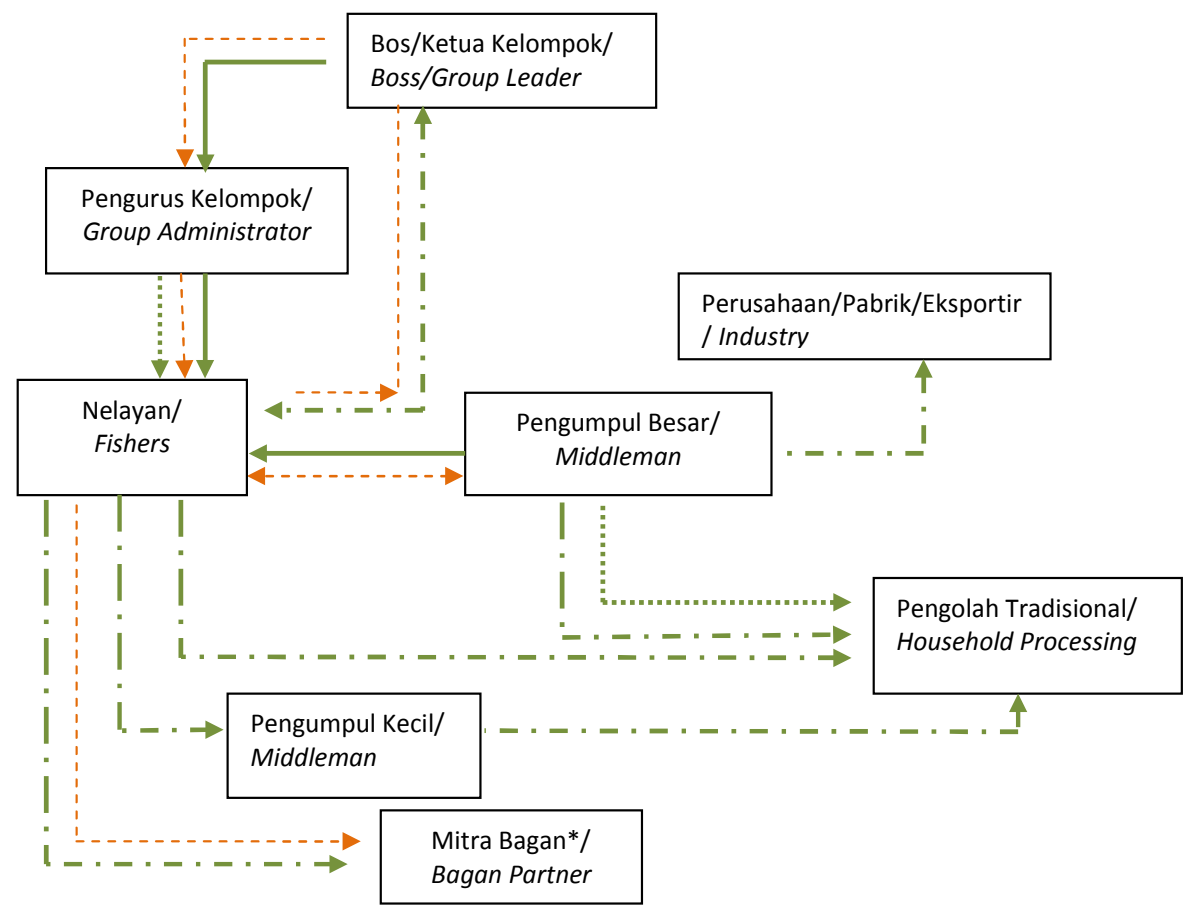

Keterangan/ Information :

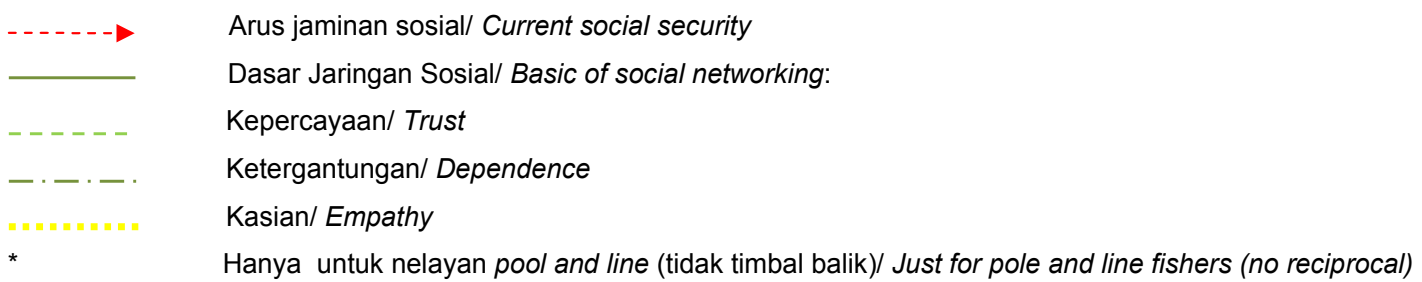

Gambar 2. Jaringan Sosial Antar Pelaku Bisnis Perikanan di TPI Sodoha Kota Kendari. Figure 2. Social Networking of the Fisheries Business Actor in TPI Sodoha Kendari. Sumber: Data primer diolah (2014)/Source: Primary data processed (2014) 
bagan dalam penyediaan umpan. Pola hubungan antara bos dengan mitra bagan tergolong dalam jenis jaringan kepentingan (Ruddy, 2007). Jaringan kepentingan yang terjadi karena nelayan pool and line ingin menjual ikan dan bos pemilik kapal memerlukan ikan untuk umpan. Ikatan dari jaringan kepentingan ini cenderung tidak kuat. Sedangkan jika dilihat dari status sosial ekonomi individu yang terlibat maka jaringan sosial antara bos dengan mitra bagan tergolong dalam jaringan sosial horizontal (Haryono, 2007).

\section{Jaringan Sosial Pedagang Pengumpul dengan Nelayan}

Ada dua pedagang pengumpul besar di Kota Kendari yang memasok ke perusahaan pengemasan ikan. Untuk menjamin kualitas dan kuantitas pasokan ikan, pedagang pengumpul membuat ikatan dengan para nelayan dengan cara memberi modal terlebih dahulu kepada nelayan, sementara pembayaran dari perusahaan baru dilakukan setelah tujuh nota pengiriman barang dari pengepul ke perusahaan. Pedagang pengumpul juga memberikan pelatihan mengenai penanganan ikan pasca penangkapan kepada nelayan yang menjadi kliennya.

Pola jaringan yang terjadi antara pedagang pengumpul dengan nelayan tergolong dalam jenis jaringan kekuasaan dan jaringan kepentingan (Ruddy, 2007). Hal ini berarti pedagang pengumpul mempunyai kewenangan atas hasil tangkapan nelayan dan nelayan harus menjual ikan ke pedagang pengumpul dengan penentuan harga mengikuti harga perusahaan atau harga pasar. Jaringan kepentingan terjalin karena pedagang dan nelayan mempunyai kepentingan masingmasing sebagai pemilik pemodal dan peminjam modal. Perbedaan jaringan nelayan dan pedagang pengumpul dengan jaringan nelayan dan bos terletak pada ikatan dari jaringan ini. Ikatan yang terjadi tidak begitu kuat karena nelayan dapat memilih pedagang pengumpul lain bukan hanya langganannya. Sedangkan jika dilihat dari status sosial ekonomi individu yang terlibat maka jaringan sosial antara bos dengan mitra bagan tergolong dalam jaringan sosial horizontal (Haryono, 2007).

\section{Jaringan Sosial Nelayan dengan Bos}

Hubungan nelayan dengan bos biasanya diperantarai oleh pengurus selaku wakil bos. Namun demikian pada kapal yang tidak mempunyai pengurus, nelayan ini akan berhubungan langsung dengan bos yang merangkap sebagai pengurus. Pengurus bertugas mencari ABK yang akan dipekerjakan di kapal. Untuk Kota Kendari, mencari ABK adalah sebuah pekerjaan yang cukup sulit. Pengurus mencari ABK hingga ke luar kota bahkan hingga lintas propinsi. Untuk menyiasatinya, tidak jarang bos mengikat nakhkoda dan ABK-nya dengan uang. Bos memberikan bonus kepada nakhkoda jika mendapatkan hasil yang bagus sebesar 10 persen.

"nakhkoda suka dapat 10\% dari hasil penjualan kalau hasilnya bagus, uang nomor 2, yang utama kepercayaan"

Pembayaran ke nelayan dilakukan setiap 5 - 7 trip atau yang diberi istilah 1 'turo'. Yang disebut 1 turo adalah dari terang bulan (istirahat) ke gelap bulan (mulai kerja). Bos yang berfungsi tidak hanya sebagai pemilik kapal namun juga pemilik modal, mengharuskan hasil tangkapan nelayan untuk dijual kepada mereka.

"kalau bukan anggota, jual ke mana saja, kalau anggota harus jual ke ketua, beda harganya dengan pasar hanya Rp. 100/kg“

Hubungan antara nelayan dengan bos/ pengurus tergolong dalam jenis jaringan kekuasaan dan jaringan kepentingan (Ruddy, 2007). Hal ini berarti bos mempunyai kewenangan penuh atas hasil tangkapan nelayan dan nelayan harus menjual ikan ke bos dengan penentuan harga dipihak bos. Jaringan kepentingan terjalin karena bos dan nelayan mempunyai kepentingan masingmasing sebagai pemilik modal dan peminjam modal. Ikatan dari jaringan ini sangat kuat karena selain dari usaha produksi dan pemasaran juga diikat secara sosial. Sedangkan jika dilihat dari status sosial ekonomi individu yang terlibat maka jaringan sosial antara nelayan dengan bos/ pengurus tergolong dalam jaringan sosial vertikal (Haryono, 2007).

\section{Keuntungan dan Kerugian Hubungan Nelayan Purse Seine dengan Pelaku Usaha Pemasaran TCT}

Hubungan nelayan dan bos di Kota Kendari terjalin harmonis tanpa merugikan sebelah pihak. Sebab, ada beberapa pola hubungan yang mengikat antara keduanya yaitu pola hubungan kerja, pola hubungan sosial, pola hubungan emosional dan pola hubungan budaya (Aini, et al., 2013). Bagi nelayan di Kota Kendari keberadaaan patron (bos) sangat membantu menunjang perekonomian 
mereka. Peran bos sangat dibutuhkan dalam kehidupan nelayan karena memiliki keuntungan yang besar yang dirasakan oleh nelayan baik secara sosial maupun ekonomi. Keuntungan dan kerugian jaringan sosial nelayan dengan pelaku usaha pemasaran TCT disajikan pada Tabel 4 .

Tabel 4. Keuntungan dan Kerugian Jaringan Sosial Nelayan Purse Seine dengan Pelaku Usaha Pemasaran TCT di Kota Kendari, 2014.

Table 4. The Advantages and Disadvantages of Purse Seine Fishers Social Networking TCT Marketing Business Actors in Kendari, 2014.

\begin{tabular}{|c|c|c|}
\hline $\begin{array}{l}\text { Jaringan Sosial / } \\
\text { Social Networking }\end{array}$ & $\begin{array}{l}\text { Keuntungan / } \\
\text { Advantages }\end{array}$ & $\begin{array}{c}\text { Kerugian / } \\
\text { Disadvantages }\end{array}$ \\
\hline $\begin{array}{l}\text { Nelayan dengan Bos/ } \\
\text { Fishers and the boss }\end{array}$ & $\begin{array}{l}\text { - Pemberian pinjaman modal untuk } \\
\text { operasional usaha penangkapan (alat } \\
\text { tangkap, bahan bakar minyak (BBM), } \\
\text { ransum melaut) / Provision of loan } \\
\text { capital for operational fishing (fishing } \\
\text { gear, fuel, meal) } \\
\text { - Kepastian pemasaran ikan/ Certainty of } \\
\text { fish marketing } \\
\text { - Penyediaan sarana penangkapan } \\
\text { (kapal) beserta anak buah kapal (ABK) / } \\
\text { Provision of ship with the crew } \\
\text { - Pemberian pinjaman untuk kebutuhan } \\
\text { mendesak keluarga (sekolah anak, sakit, } \\
\text { dll) / Provision of loans for urgent need } \\
\text { families (children school, illness, etc.) } \\
\text { - Pembayaran pinjaman bisa sewaktu- } \\
\text { waktu dan tidak dipotong dari hasil } \\
\text { tangkapan / Loan payments may at any } \\
\text { time and are not deducted from the catch }\end{array}$ & $\begin{array}{l}\text { - Penentuan harga menjadi } \\
\text { wewenang bos / Pricing is the } \\
\text { authority of the boss } \\
\text { - Harga tidak mengikuti informasi } \\
\text { pasar / Price does not followed by } \\
\text { market information } \\
\text { - Ketergantungan dengan bos / } \\
\text { Dependence with the boss }\end{array}$ \\
\hline
\end{tabular}

Bos dengan Mitra Bagan/

Boss and bagan partner
- Pemberian modal untuk sarana penangkapan (genset dan lampu) / Providing capital for catching means (generators and lights)

- Memiliki kepentingan yang sama (penjual dan pembeli ikan umpan) / Having the same interests (sellers and buyers of fish bait)
- Ikatan tidak terlalu kuat karena mitra bagan bebas menjual hasil tangkapan / The bond is not very strong because the partners are free to sell the fish catch

- Modal yang diberikan oleh bos menjadi hangus jika penjualan ikan tidak kepada bos / Capital provided by the boss be forfeited if the sale of fish is not to boss

\begin{tabular}{|c|c|c|}
\hline $\begin{array}{l}\text { Nelayan dengan Pedagang } \\
\text { Pengumpul/Fishers and } \\
\text { middleman }\end{array}$ & $\begin{array}{l}\text { - Pemberian modal untuk operasional } \\
\text { penangkapan ikan /Providing capital for } \\
\text { fishing operations } \\
\text { - Pemberian pelatihan intensif mengenai } \\
\text { handling pasca penangkapan / Providing } \\
\text { intensive training on handling post- } \\
\text { harvest }\end{array}$ & $\begin{array}{l}\text { Ikatan tidak terlalu kuat karena } \\
\text { nelayan tidak terikat secara sosial } \\
\text { dengan pedagang pengumpul } \\
\text { / The bond is not very strong } \\
\text { because the fishers are not socially } \\
\text { bound with traders }\end{array}$ \\
\hline $\begin{array}{l}\text { Nelayan / Pedagang } \\
\text { Pengumpul dengan } \\
\text { Pengolah Ikan Skala } \\
\text { Industri / Fishers / Middle } \\
\text { man and household fish } \\
\text { processing }\end{array}$ & $\begin{array}{l}\text { - Penjualan ikan cepat sehingga kualitas } \\
\text { terjamin / Sales of fish quickly so quality } \\
\text { is assured }\end{array}$ & $\begin{array}{l}\text { - Harga jual lebih rendah } \\
\text { dibandingkan harga pasar (margin } \\
\text { Rp } 2.000 / \mathrm{kg} \text { ) / The selling price is } \\
\text { lower than the market price (margin } \\
\text { of } R p 2,000 / \mathrm{kg} \text { ) } \\
\text { - Tidak ada ikatan yang kuat karena } \\
\text { nelayan bebas menjual ikan } \\
\text { kemanapun / No strong bond due to } \\
\text { free fishers sell fish wherever } \\
\text { - Sistem pembayaran lama (1 minggu } \\
\text { s.d } 1 \text { bulan) / Longer payment } \\
\text { systems (1 week until } 1 \text { month) }\end{array}$ \\
\hline
\end{tabular}

Sumber: Data primer diolah (2014)/Source: Primary data processed (2014) 
Secara umum, berdasarkan empat jaringan sosial nelayan purse seine dengan pelaku usaha pemasaran TCT yang ada, maka peran jaringan sosial yang diharapkan mampu meningkatkan efisiensi penangkapan dan pemasaran TCT adalah jaringan sosial nelayan dengan bos, karena memiliki keuntungan yang lebih besar daripada kerugiannya baik sosial maupun ekonomi. Jaringan sosial ini dapat dikembangkan dengan menerapkan formulasi bentuk pola kemitraan inti-plasma atau yang terkenal dengan pola kemitraan Perusahaan Inti Rakyat (PIR). Bos sebagai inti sedangkan nelayan sebagai plasma dalam menjalankan usaha penangkapan ikan. Bos menyediakan modal usaha dan memasarkan hasil produksi, sedangkan nelayan berkewajiban menjual hasil tangkapan ikan kepada bos. Aturan-aturan, fungsi peran masing-masing komponen diatur dalam bentuk kesepahaman. Pemerintah dapat berfungsi sebagai fasilitator dalam manajemen keuangan. Bantuan dari Kementerian Kelautan dan Perikanan (KKP) melalui program PNPM Mandiri KP pada usaha perikanan diharapkan dapat dikelola dengan baik oleh masyarakat perikanan. Pengelolaan keuangan dilakukan dengan pembentukan koperasi nelayan yang mengatur sistem simpan-pinjam dan jangka waktu peminjaman uang untuk modal usaha.

\section{KESIMPULAN DAN IMPLIKASI KEBIJAKAN}

\section{Kesimpulan}

Karakteristik nelayan di Kota Kendari memiliki perbedaan terhadap jenis ikan yang ditangkap berdasarkan alat tangkap yang digunakan. Sistem pemasaran terdiri dari 6 (enam) saluran pemasaran dengan tujuan pemasaran tingkat lokal, luar kota/ pulau maupun luar negeri yang melibatkan berbagai aktor yang mengembangkan jaringan sosial.

Jaringan sosial antar nelayan dengan bos tidak hanya terbatas pada jaringan kerja produksi saja, namun atas kehidupan sosial lainnya. Keuntungan yang diperoleh dari jaringan ini bagi nelayan secara sosial adalah motif tolong menolong terhadap sesama (empati) dan bantuan saat adanya keperluan mendesak untuk usaha maupun keluarga. Sedangkan keuntungan secara ekonomi adalah pemberian modal usaha penangkapan, kepastian pemasaran ikan, dan penyediaan anak buah kapal (ABK) beserta penyediaan kapal.

Jaringan sosial yang sesuai dan prospektif dalam meningkatkan efisiensi usaha penangkapan dan pemasaran untuk dikembangkan di Kota Kendari adalah jaringan sosial antara nelayan dengan bos yang dapat dilakukan dengan pola kemitraan inti-plasma.

\section{Implikasi Kebijakan}

Untuk mewujudkan jaringan sosial antara nelayan dengan bos dengan pola kemitraan inti-plasma dengan tujuan meraih keuntungan bersama dengan prinsip saling membutuhkan dan saling membesarkan usaha perikanan maka diharapkan (1) peran pemerintah daerah melalui Dinas Kelautan dan Perikanan Kota Kendari untuk menginisiasi pembentukan kelompok nelayan, pengurus, aturan main dalam kelompok nelayan tersebut serta melakukan pembinaan secara rutin untuk penguatan kapasitas anggota kelompok dalam kegiatan usaha penangkapan dan pemasaraan perikanan; (2) pembentukan koperasi yang berfungsi sebagai penyediaan pinjaman modal dan penyimpanan uang hasil tangkapan sehingga nelayan dan bos dapat berperan secara sehat dalam pemasaran ikan TCT , dan (3) bantuan pemerintah khususnya Kementerian Kelautan dan Perikanan yang berfungsi sebagai inti yang siap membeli hasil tangkapan nelayan yang berfungsi sebagai plasma dengan terlebih dahulu membuat kesepakatana atau perjanjian kerjasama antara inti dan plasma.

\section{DAFTAR PUSTAKA}

Aini, S., E. Yulinda \& Kusai. 2013. Pola Hubungan Nelayan dengan Tauke di Kepenghuluan Teluk Pulau Hulu Kecamatan Rimba Melintang Kabupaten Rokan Hilir Provinsi Riau. Skripsi, Fakultas Perikanan dan IImu Kelautan. Universitas Riau. Riau.

Amiruddin, S. 2014. Jaringan Sosial Pemasaran pada Komunitas Nelayan Tradisional Banten. Jurnal Komunitas 6 (1):106-115.

Badan Pusat Statistik (BPS). 2013. Kota Kendari dalam Angka 2012. BPS Kota Kendari. Kendari.

Cavana, R. Y., B. L. Delahaye \& U. Sekaran. 2000. Applied Business Research : Qualitative and Quantitative Methods. Australia: John Wiley and Sons Autralia Ltd.

Harini, D. N. 2012. Dari Miyang Ke Longlenan: Pengaruh Jaringan Sosial Pada Transformasi Masyarakat Nelayan. Jurnal Komunitas 4 (2):178-190. 
Haryono, T. J. S. 2007. Jaringan Sosial Migran Sekuler: Analisis tentang Bentuk dan Fungsi. Jurnal Masyarakat, Kebudayaan dan Politik $20(2): 5-15$.

Lawang, R.M.Z. 2005. Kapital Sosial dalam Perspektif Sosiologi. Cetakan Kedua. FISIP UI Press, Depok.

Mirajiani, E.S., Wahyuni, A. Satria, Saharuddin \& T. Kusumastanto. 2014. Transformasi Pranata Patronase Masyarakat Nelayan: Dari Ekonomi Moralitas Menuju Ekonomi Pasar. Jurnal Komunitas 6 (1) : 115-134.

Nazir, M. 1988. Metode Penelitian. Ghalia Indonesia. Jakarta.
Ningsih, R., S. Panji \& H. Sri, 2009. Jaringan Sosial dan Jaringan Pemasaran pada Komunitas Nelayan. Thesis. Fakultas IImu Sosial dan Politik. Universitas Mercu Buana. Jakarta.

Ruddy, A. 2007. Teori Sosiologi Modern. Prenada Media. Jakarta.

Sallatang, M. A. 1982. Pinggawa Sawi, Suatu Studi Sosiologi Kelompok Kecil. Disertasi. Fakultas Perikanan dan IImu Kelautan. Universitas Hasanuddin. Makassar.

Syahyuti. 2008. Peran Modal Sosial (Social Capital) dalam Perdagangan Hasil Pertanian. Forum Penelitian Agro Ekonomi 26 (1) : 32-43. 


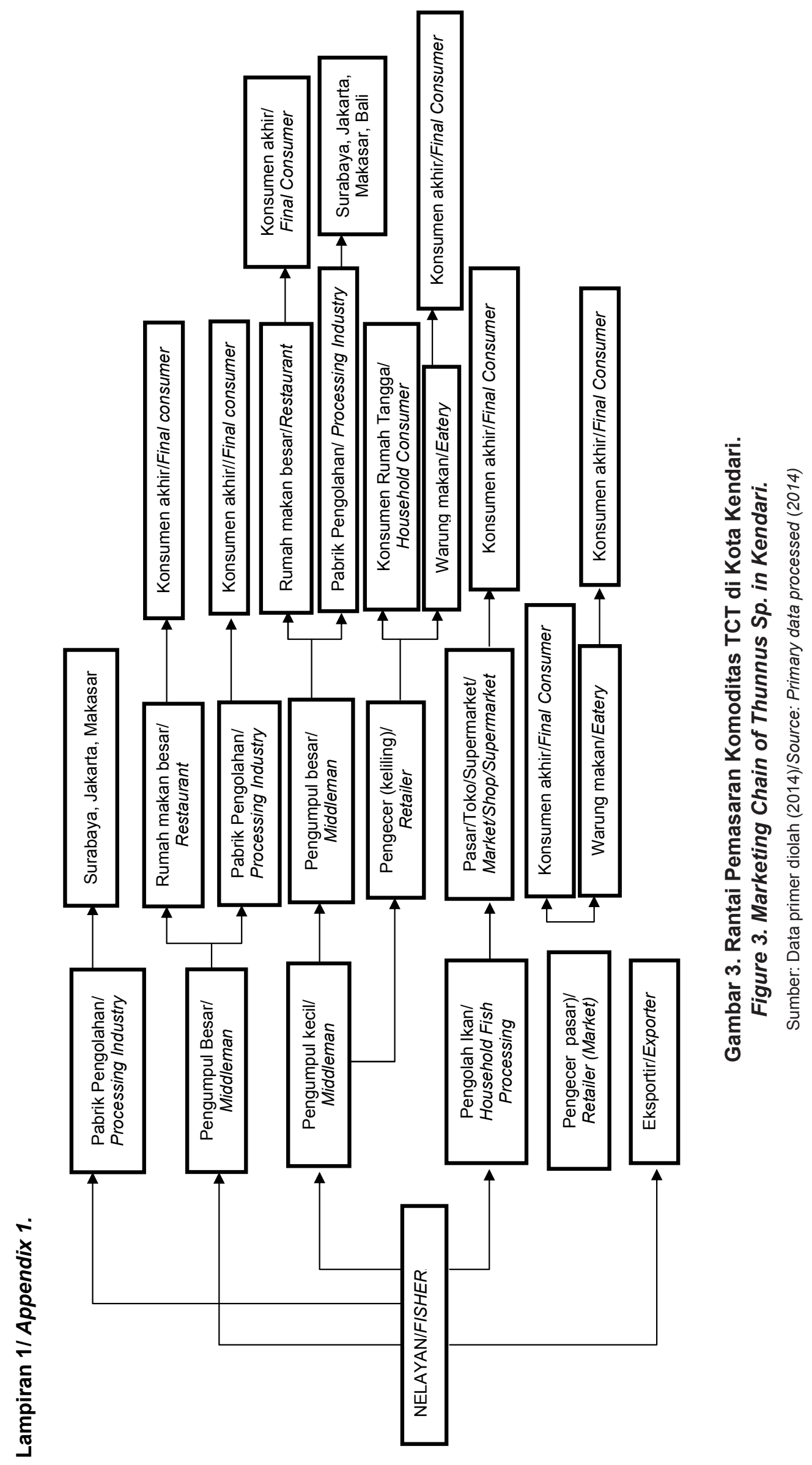

